\title{
CUSTOMER LOYALTY PROGRAM AS A TOOL OF CUSTOMER RETENTION: LITERATURE REVIEW
}

\author{
Magdalena Hofman-Kohlmeyer ${ }^{1}$
}

\begin{abstract}
Customer loyalty is a highly valuable asset. To gain loyalty of current customers and create attachments, the growing ranks of entrepreneurs decide on implementation of loyalty programs. This article aims at providing a theoretical outlook on various approaches on loyalty programs derived from literature review and identifing the factors which lead to success of a company. The literature review offers some directives for managers which are useful in the preparation of rewarding programs and are also a source of valuable customer information that helps in building future marketing strategies. We concluded that loyalty programs impact customers using financial and psychological factors to maintain long-term loyalty. Furthermore, loyalty programs should include financial as well as affective components as only financial incentives don't guarantee a long-term relationship.
\end{abstract}

JEL Classification Number: M31, DOI: http://dx.doi.org/10.12955/cbup.v4.762

Keywords: loyalty program, customer loyalty, customer retention.

\section{Introduction}

In the last couple of years, the role of customer loyalty in a company's performance has been widely acknowledged. It is known that there is a positive relationship between customer loyalty and profitability. Companies try to build long lasting relationships with customers as the feelings of attachment leads to generation of higher profits. Entrepreneurs are looking for progressive tools to maintain customer satisfaction and interest resulting in regular purchases. Successful loyalty programs can help convert satisfied customers to loyal customers which protects market shares over time. (Vinod, 2011).

This article aims at providing an outlook on various approachs on customer loyalty programs as a tool for customer retention derived from literature review. Managers should identify important factors leading to a successful program.

To achieve this goal, the first part of this analysis focuses on the definitions of customer loyalty. The second part refers to customer loyalty programs in literature review. The final part of the article offers conclusions based on the mentioned literature review and states some directives that could be valuable to managers.

\section{Customer loyalty}

According to Tabaku and Zerellari (2015), there are two approaches on customer loyalty: behavioral and attitudinal. The behavioral approach on customer loyalty refers to the customer consistently and continuously buying from the same provider. Whereas, attitudinal loyalty is a result of a psychological connection with the product or service, involving a preference and components like a positive attitude and commitment.

Ludin \& Cheng (2014) describe customer loyalty as a continuous relationship between the customer and the brand. It can be seen as resistance to switch brands inspite of any situation or problem encountered during the business process. Additionally, they describe customer loyalty as repeated purchases of a product from the same brand.

Loyalty behaviors show an increase in number of purchases, an increase in number of customers and lower price sensitivity (Varela-Neira, Vazquez-Casielles \& Iglesias, 2010). Loyal customers guarantee a reduction in marketing costs for long periods of time. (Mascarenhas, Kesavan \& Bernacchi, 2006).

\section{Loyalty programs}

Loyalty programs have existed for 30 years. American Airlines was the first to launch a loyalty program and called it "Frequent Flyer Program". This program was based on the fundamental statement that all customers are not created equal. Thereafter, loyalty programs have disseminated into

\footnotetext{
${ }^{1}$ Magdalena Hofman-Kohlmeyer, Faculty of Management, University of Economics in Katowice, Katowice, Poland, magdahofman@o2.pl
} 
hotels, rental car, financial services and restaurants. Over the years, loyalty program have become prevalent (Vinod, 2011). Loyalty programs are a marketing strategy focused on offering benefits to achieve loyal customer retention. These programs are also called frequent purchase programs or reward programs because benefits depend on purchasing frequency (Gómez, Arranz, Cillán \& 2006).

Meyer-Waarden (2008) states previously used definition of loyalty programs as an integrated system of marketing actions that aims at making customers more loyal by developing a personalized relationship with them. Developing approach treats customer loyalty program as a tool for relationship management. This tool gives an opportunity to create personalized communication. Companies record information by loyalty cards and possess instruments of dissemination and individualization of marketing mix (Meyer-Waarden, 2008). It enables managers to hold customers data and create customer databases. Collected data may be exploited for many reasons, like price discrimination, direct marketing, customer profiling and to promote products. However, it must be kept in mind that customers are afraid of losing their personal data and expect appropriate privacy protection therefore, customer loyalty is reliant on the customer's trust in the company. Creation of safe customer profiles can address this issue and will help attract privacy sensitive customers (Enzmann \& Schneider, 2005).

Gómez, Arranz \& Cillán (2006) emphasize that customer loyalty program have to build behavioral and affective loyalty. According to behavioral approach, loyalty program play an important role in the purchase frequency. Participants in this program make a higher number of visits to the retailer than non-participants.

\section{Key components for developing Loyalty}

The key components for developing affective loyalty are: attitude, satisfaction, trust and commitment.

- Attitude is a lasting affection towards an object or an experience. Positive attitude is inevitable to build a true loyalty (Gómez, Arranz \& Cillán, 2006).

- Satisfaction is defined as an evaluation of the perceived discrepancy between prior expectation and the actual performance of the product. In the context of services, perceived satisfaction is related to confirmation or disconfirmation of expectations (Sahin Dölarslan, 2014).

- Trust is a key factor to make customers loyal. Service or product suppliers should gain the trust of a customer and ensure them that the transmitted data is confidential.

- Commitment is when there is a rational and affective bond in the relationship. Some authors admit that there is no customer loyalty without emotional aspects. Only repeated transactions is not enough for loyalty to last (Gómez, Arranz \& Cillán, 2006).

Hoffman \& Lowitt (2008) indicate the importance of the way managers run loyalty programs. It is vital to maintain a customer's loyalty for a long time. Incentive not only lure customers into occasional purchase but also enhance loyalty. The expiration dates on loyalty cards enable managers to achieve short term financial goals. Customers will probably try firm's offering, but it is difficult to determine what products they may choose next time. Loyalty programs not only have financial benefits but provide customers with a feeling of intelligence and pride when they buy something for a better price or get something free (Hoffman \& Lowitt, 2008), especially when something is expensive. When buyers feel like special customers, they start to identify more strongly with the company (MeyerWaarden, 2008).

\section{Rewarding Systems and Virtual Communities}

Within the last couple of years the role of the Internet in business has been widely acknowledged, especially when it comes to selling products via e-shops. In terms of e-commerce, there are two different types of programs: rewarding system and virtual communities. Rewarding systems give members financial benefits (Enzmann \& Schneider, 2005). The popular form is based on cash-back reward program where suppliers pay certain amount of money for every qualified purchase which is a fixed percentage of purchase amounts. This kind of rewarding program causes increase in sales in a short interval of time but customers don't necessarily repeat purchases (Altinkemer \& Ozcelik, 2009).

Virtual communities refer to social aspects, like an online discussion panel on product related problems (Enzmann \& Schneider, 2005). Since social media became popular, loyalty program have 
started to use Facebook, Twitter and Linkedin for marketing purposes where firms communicate with members about offers and promotions (Vinod, 2011).

\section{Equity-based Loyalty Programs}

Altinkemer \& Ozcelik (2009) describe new types of electronic loyalty programs. The alternative of solutions mentioned above is equity-based loyalty program where customers become fractional owners of the firms. Customers collect shares instead of discounts but the amount of equity is very small, usually around one percent of unit share. Howve, it is not possible to implement this program without IT applications and the Internet. In this model, customers are obligated to go back to the same firm after an initial purchase (Altinkemer \& Ozcelik, 2009).

\section{Benefits of Loyalty Programs}

Meyer-Waarden (2008) carried out survey in retail outlets to examine the effects of loyalty cards on the behavior of customers. As a result, during the three-year period, card owners demonstrated higher number of purchase and higher loyalty than average. He concluded that loyalty programs cause a decrease of degree of price sensitivity in a customer's mind, and the buyers are ready to pay more than usual. Furthermore, loyalty is always followed by an increase in number of purchases.

Tahal (2014) carried out a research about customer loyalty programs in electronic commerce. He gathered information on companies that are running e-shops and asked opinions of people who were typical online customers. On identifying the company's expected benefits of the loyalty program, the following result were obtained (shown in Figure 1):

- the company's reputation advanced by $73 \%$,

- brand awareness increased by $95 \%$,

- profit increased by $77 \%$,

- turnover increased by $100 \%$, and

- number of repeated purchases increased by $95 \%$

Figure 1: Company benefits from using loyalty program

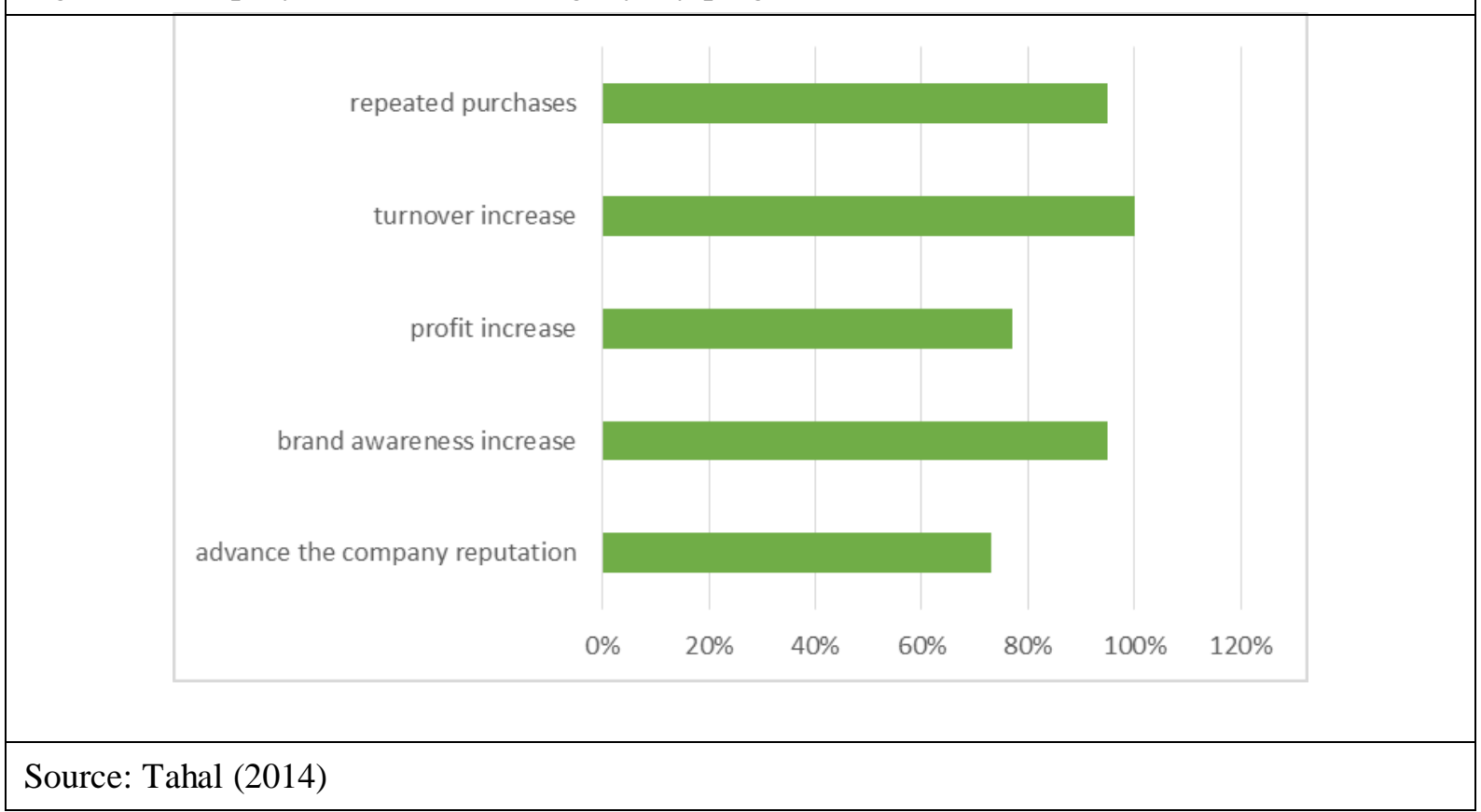

Tahal (2014) also indicated benefits from buyers point of view. Loyalty program attracted customer by using incentives such as, discount on selected items, remuneration based on points gathering, listing to the valuable gift draw, gifts (small free items), instant quantity discounts, money voucher for the next purchase, flat discounts on the favorite items and other incentives (Shown in Figure 2). 
Figure 2: Buyers benefits from using loyalty program

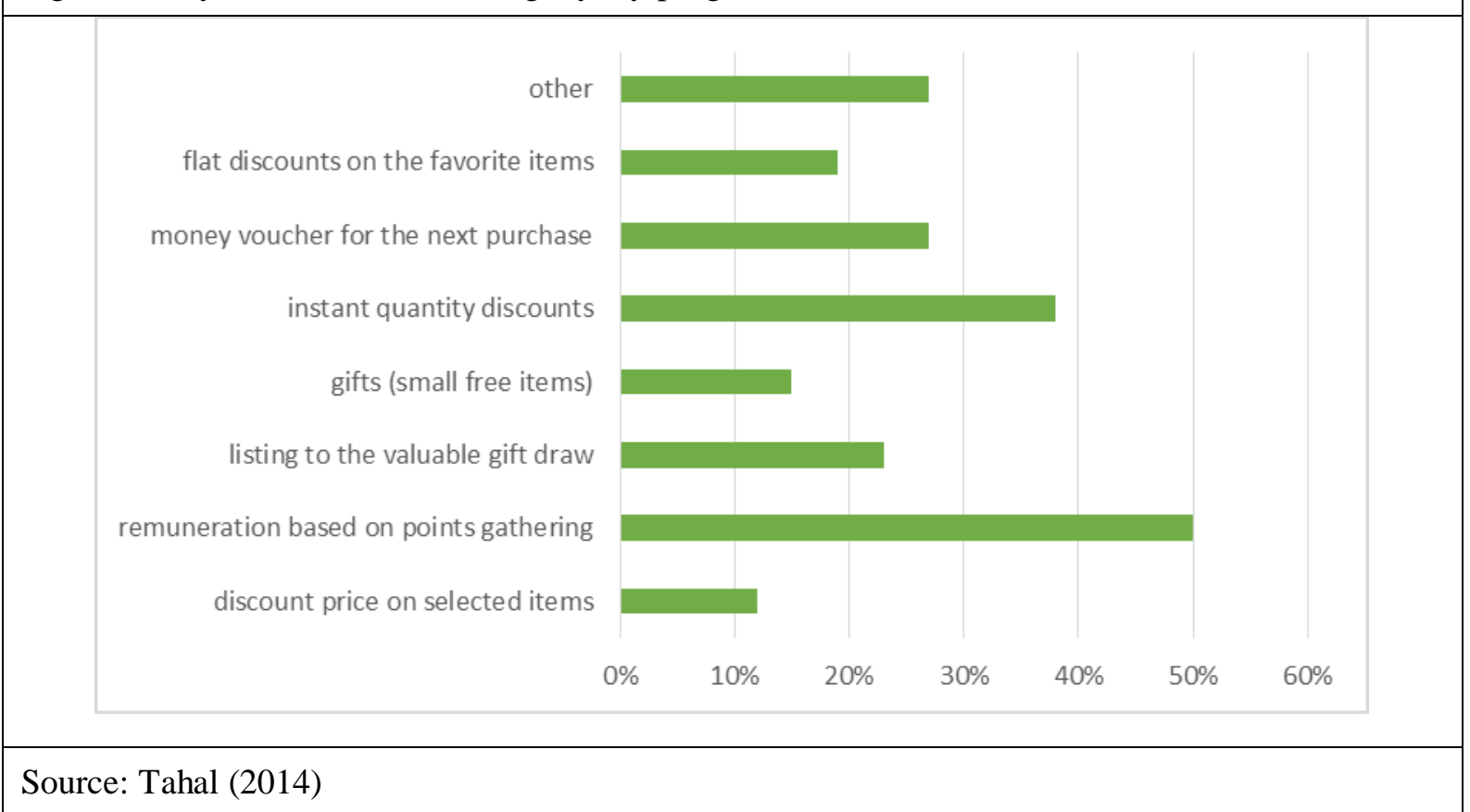

Loyalty programs provides many advantages such as an increase in sales revenues and a closer bond between current customers and the brand (Khan, 2014).

Customers may shift products and services to look for better value or price all the time and from an entrepreneural point of view, of is important to reduce these customer shifts. Managers try to outsmart their competitors using various marketing tools to maintain customer loyalty (Bose \& Rao, 2011).

\section{Conclusion}

This paper gives a theoretical approach on influence of loyalty program on customers' loyalty and profitability of the company. Literature review contains many approaches on loyalty programs for managers.

Many authors emphasize that loyalty programs contain financial and affective components. Only financial benefits don't guarantee retention of the customer. Customer reward program is a source of valuable information and is important to build customer knowledge databases. Collected data should be the basis for development of a marketing strategy. Managers must protect the privacy of the customers as customer loyalty is reliant on the customer's trust on the company.

Conclusively, loyalty programs are profitable because it is less expensive to retain existing customers than to attract new ones (Altinkemer \& Ozcelik, 2009).

\section{References}

Altinkemer, K., \& Ozcelik, Y. (2009). Cash-back rewards versus equity-based electronic loyalty programs in e-commerce. Information Systems and eBusiness Management, 7(1), 39-55. doi:http://dx.doi.org/10.1007/s10257-007-0062-0

Bose, S., \& Rao, V. G. (2011). Perceived benefits of customer loyalty programs: validating the scale in the Indian context. Management \& marketing, 6(4), 543-560. Retrieved from http://search.proquest.com/docview/918645127?accountid=45580

Sahin Dölarslan, E., (2014). Assessing the effects of satisfaction and value on customer loyalty behaviors in service environments. High-speed railway in Turkey as a case study. Management Research Review, 37(8), 706-727. Retrieved from http://search.proquest.com/docview/1651370188?accountid=45580

Enzmann, M., \& Schneider, M. (2005). Improving Customer Retention in E-commerce through a Secure and PrivacyEnhanced Loyalty System. Information Systems Frontiers, 7(4-5), 359-370. doi:http://dx.doi.org/10.1007/s10796-005-4808-2

Gómez, B. G., Arranz, A. G., \& Cillán, J. G. (2006). The role of loyalty programs in behavioral and affective loyalty. Journal of Consumer Marketing, 27(3), 387-397. doi:http://dx.doi.org/10.1108/07363760610712920

Hoffman, J. L., \& Lowitt, E. M. (2008). A better way to design loyalty programs. Strategy \& Leadership, 36(4), 44-47. doi:http://dx.doi.org/10.1108/10878570810888777 
Khan M. T. (2014). Customer Loyalty Programs - Concept, Types, Goals and Benefits (A Conceptual and Review Paper). International Journal of Information, Business and Management, 6(1), 74-93. Retrieved from http://search.proquest.com/docview/1511381985?accountid=45580

Ludin, I. H. B.H., \& Cheng, B. L. (2014). Factors Influencing Customer Satisfaction and E-Loyalty: Online Shopping Environment among the Young Adults. Management Dynamics in the Knowledge Economy, 2(3), 462-471. Retrieved from http://search.proquest.com/docview/1646545655?accountid=45580

Mascarenhas, O. A., Kesavan, R., \& Bernacchi, M. (2006). Lasting customer loyalty: a total customer experience approach. The Journal of Consumer Marketing, 23(7), 397-405. doi:http://dx.doi.org/10.1108/07363760610712939

Meyer-Waarden, L. (2008). The influence of loyalty programme membership on customer purchase behavior. European Journal of marketing, 42(1), 87-114. doi:http://dx.doi.org/10.1108/03090560810840925

Tabaku, E., \& Zerellari, M. (2015). Brand loyalty and loyalty programs; a literature review. Romanian Economic and Business Review, 10(2), 87-102. Retrieved from http://search.proquest.com/docview/1700066812?accountid=45580

Tahal, R., (2014). Loyalty programs in e-commerce and their perception by the young adult internet population. Central European Business Review, 3(2), 7-13. Retrieved from http://search.proquest.com/docview/1647600101 accountid=45580 Varela-Neira, C., Vazquez-Casielles, R., \& Iglesias, V. (2010). Explaining customer satisfaction with complaint handling. The International Journal of Bank, 28(2), 88-112. doi:http://dx.doi.org/10.1108/02652321011018305

Vinod B. (2011). Unleashing the power of loyalty programs - The next 30 years. Journal of Revenue and Pricing Management, 10(5), 471-476. doi:http://dx.doi.org/10.1057/rpm.2011.11 